\title{
Authorship Controversy in Three Greek Epigrams: Phalaecus Revived
}

Krzysztof Tomasz Witczak

(University of Łódź)

\begin{abstract}
The author discusses authorship controversies connected with three Greek epigrams: AP VI



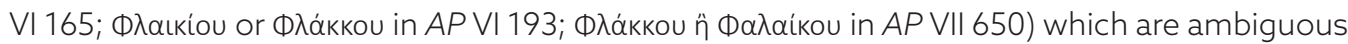
and they may refer to two different epigrammatists, namely Phalaecus of Phocis or Phlaccus (Lat. Statyllius Flaccus). It is suggested that these epigrams represent Phalaecus' literary output.
\end{abstract}

\section{Keywords}

Greek epigrams; Palatine Anthology; Phalaecus of Phocis; Statyllius Flaccus 
Fourteen years ago I discussed the controversial problem of the authorship of the epigram AP VI 193, whose lemma seems uncertain or ambiguous (scribe A wrote: $\Phi$ גaıkiou

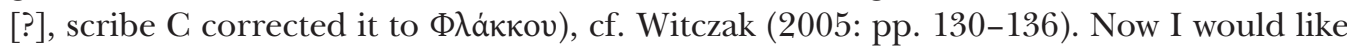
to return to the question once more, as the problem of the authorship is more complex. There are three epigrams in the Palatine Anthology where the name of Phalaecus

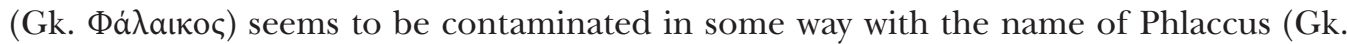

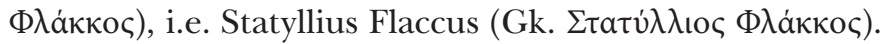

The first instance is the epigram $A P$ VI 165, where the author's lemma is evident-

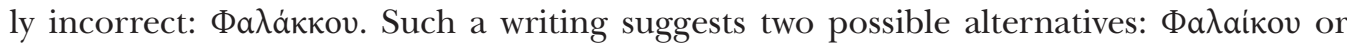
Фһáккоv. It is completely uncertain who the author of the epigram in question was. Modern scholars hesitate whether Phalaecus of Phocis or Statyllius Flaccus should be assumed as the author of AP VI $165 .^{1}$

The second controversy refers to the poetical masterpiece AP VI 193. The scribe A, copying the edition of Constantine Cephalas, introduced author's lemma $\Phi$ גaкkiov (?), but the scribe $\mathrm{C}$ (acting as a corrector) changed it into $\Phi \lambda$ áккоv. It is uncertain whether corrector's emendation was motivated or not.

The third problem is connected with the epigram AP VII 650. The Palatine codex

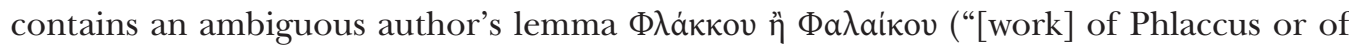
Phalaecus"), whereas the Planudean codex, created in 1301 A.D. by Maximus Planudes,

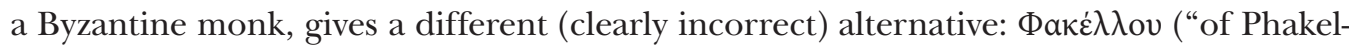
lus").

\section{Epigrams of Phalaecus}

Phalaecus of Phocis was an early Hellenistic lyric and epigrammatic poet, who lived in the second part of the fourth century and the first part of the third century B.C. (Skiadas 1967-1968: pp. 65-67; Albiani 2007: p. 906; Appel 2017: pp. 13-18). Phalaecus' works

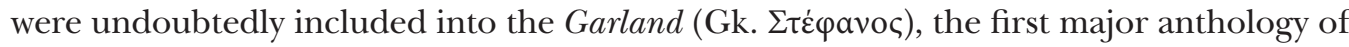
epigrams, created by Meleager of Gadara (first century BC). However, the author of the Garland did not mention Phalaecus' name among other poets in the preserved preface (AP IV 1) to his anthology of the Greek epigrams (Tueller 2014: pp. 175-181). Only five of obvious Phalaecus' epigrams are still preserved in the Greek Anthology, the sixth one is quoted by Athenaeus (Deipnosophistae X 440d), cf. Skiadas (1967-1968: pp. 68-86).

It is worth emphasizing that the Aeolic lyric metre called commonly the Phalaecian

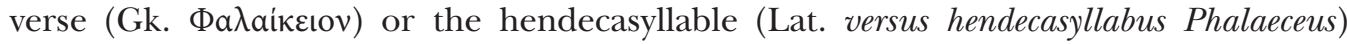
was named after him. The metre in question was older than the Hellenistic times and therefore Skiadas (1967-1968: pp. 67-68) suggests that Phalaecus of Phocis was not an

1 Waltz (1960: p. 91) after Bouhier attributes the epigram AP VI 165 to Phalaecus of Phocis, but he indicates a different opinion in his apparatus criticus ("Statyllio Flacco tribuunt Knaac, Sitzler, Wilamowitz"). Also Appel (2017: p. 15) informs about doubts of modern science: "it is assumed that he [i.e. Phalaecus] is the author of two further epigrams preserved in Anthology (VI 165 and VI 193), whose authorship is also attributed to another poet, namely Statyllius Flaccus" (my translation). 
inventor of this lyric measure, but he frequently used it in his epigrams. Also the Roman poets adopted and used the same metre. Though the modern scholars know little about Phalaecus, there is a general agreement that he was one of the principal Alexandrian poets.

\section{Epigrams of Statyllius Flaccus in the Greek Anthology}

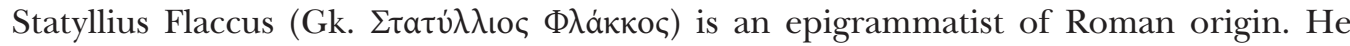
lived in the first century BC and his epigrams were included in the Philip's Garland (Albiani 2004: p. 448). He is frequently identified with Statilius Flaccus, a supporter of epicureanism, who died in 42 BC at Philippi (Davico Bonino 2000: p. 287).

It should be noted that all these epigrams, which were obviously issued by Statyllius Flaccus, are generally signed with both a family name (Latin nomen gentile vel nomen gentilicium), i.e. Statyllius (Statilius), and a nickname (Latin cognomen), i.e. Flaccus. Only in two cases, the same nickname appears ( $A P$ VII 542; AP XII 12). Here is a list of all the epigrams of Statyllius Flaccus contained in the so-called Greek Anthology:

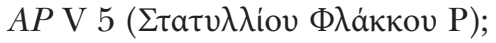

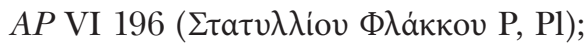

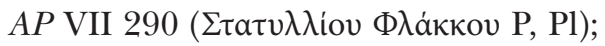

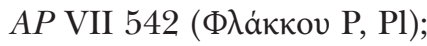

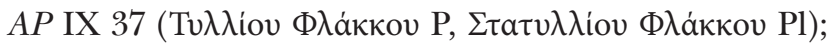

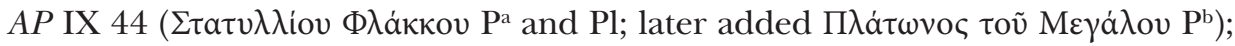

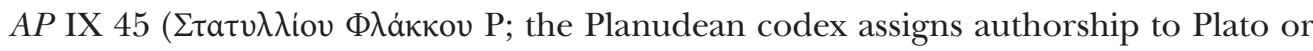
Antipater);

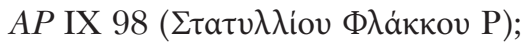

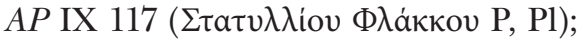

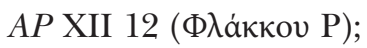

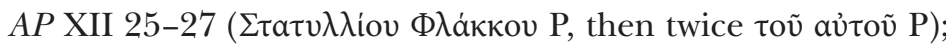

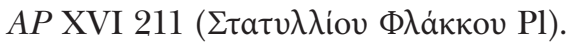

The name of this Roman epigrammatist is not subject to corruption except for one

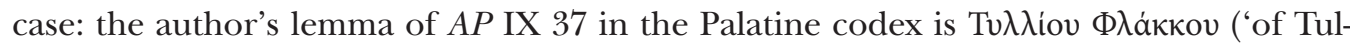
lius Flaccus') instead of $\Sigma \tau \alpha \tau u \lambda \lambda$ iov $\Phi \lambda$ ákкоv ('of Statyllius Flaccus'). It is easier for the later copyists to alter the rather unusual name of Phalaecus than the surname of Statyllius Flaccus.

\section{The authorship of AP VII 650}

Having discussed the problem of the writer's lemmas concerning Phalaecus and Statyllius Flaccus in the preserved manuscripts of the Greek Anthology, I intend to review the problem of the authorship in three dubious instances. I begin my investigations from AP VII 650. 
The text of the epigram runs as follows:

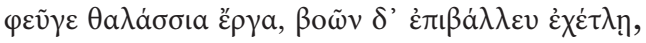

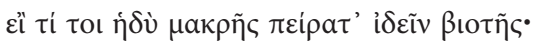

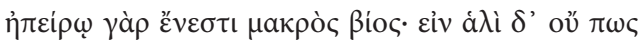

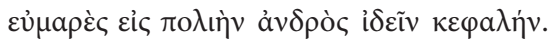

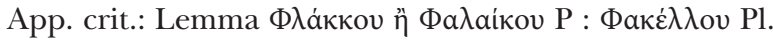

English translation: "Avoid busying thee with the sea, and put thy mind to the plough that the oxen draw, if it is any joy for thee to see the end of a long life. For on land there is length of days, but on the sea it is not easy to find a man with grey hair." Translated into English by Paton (1960b: p. 347).

The text is written in the epic (Ionic) dialect. Its essence and contents exclude the possibility of attributing it to Phalaecus or Statyllius Flaccus. Let's discuss writer's lemmas.

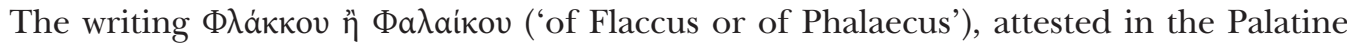
codex, demonstrates clearly that a Byzantine copyist was not sure who the author of the

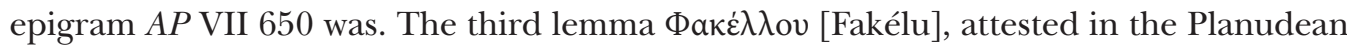
codex, could have been successfully created by distorting the name Фa入aikov [Faléku] ('of Phalaecus') as a result of the erroneous metathesis of phonemes $(k-l<l-k)$. It is extremely difficult to show how and why the lemma Ф入а́ккоv could be distorted and changed into the saved form $\Phi$ aki่ $\lambda \lambda$ ov. Therefore, the epigram AP VII 650 should be assigned to Phalaecus based on the author's lemmas in both (Palatine and Planudean) codices.

The modern editors attribute commonly the epigram AP VII 650 to Phalaecus of Phocis. So did Stadtmueller (1899: p. 445), Paton (1960b: p. 347), Waltz (1960a: p. 129), Gow \& Page (1965: p. 464), Skiadas (1967-1968: p. 69), Page (1974: p. 74) and Appel (2017: p. 17). Others continue the ancient controversy, e.g. Ebener (1981: p. 176), who assumes: "Statilius Flaccus oder Phalaikos".

The British scholars comment on the controversy in the following way: "The variety presented in the author's name is plainly due to illegibility at some stage in the tradition. A.P.7.646-655 are, however, firmly Meleagrian, and Statyllius Flaccus may be ruled out as author. There seems therefore no reason to question the attribution to Phalaecus" (Gow \& Page 1965: p. 464). I completely agree with their opinion.

\section{The authorship of AP VI 193}

The epigram in question, like the one discussed earlier (AP VII 650), is written in the literary Ionic dialect. It describes Damoetas, an old Greek fisherman, who, having reached a pensionable age, dedicates his nets to Priapus.

The Greek text runs as follows:

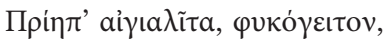

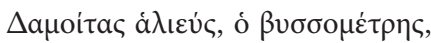




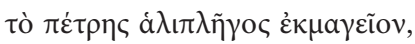

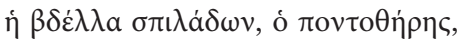

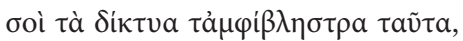

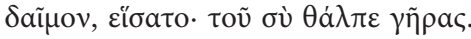

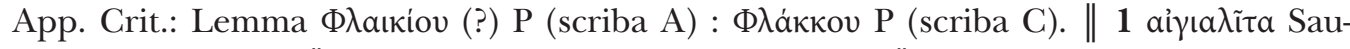

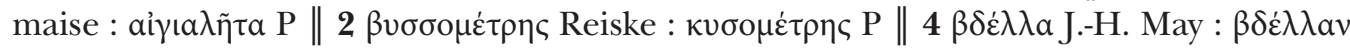

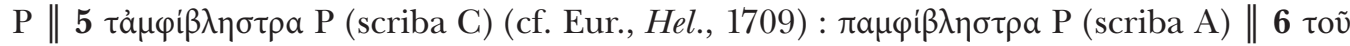

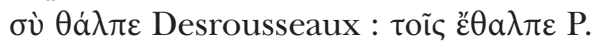

English translation: "Priapus of the beach, neighbour of the sea-weed, Damoetas the fisherman, the fathomer of the deep, the very image of a sea-worn crag, the leech of the rocks, the sea-hunter, dedicates to thee the sweep-net, with which he conforted his old age." Translated into English by Paton (1960a: p. 399).

Not all editorial corrections are obvious or necessary. The final phrase can be restored without any change (

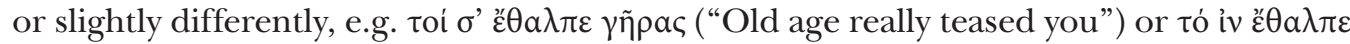

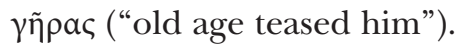

Stadtmueller (1894: p. 325) and Waltz (1960: p. 103) reject Phalaecus as the author of the epigram AP VI 193 and, at the same time, they prefer the authorship of Statyllius Flaccus. Is this position correct? I don't think so.

Let us review afresh the problem of the authorship of the epigram AP VI 193. The

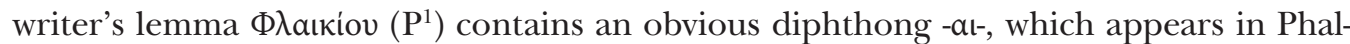
aecus' name, but not in the name of (Statyllius) Flaccus. This is why the corrected lemma $\Phi \lambda$ ákкov seems wrong. The ending -iov, instead of the expected one -ov, seems second-

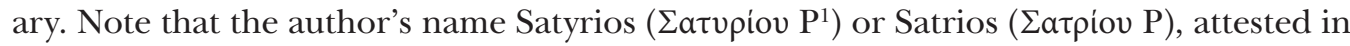
the Palatine codex under the lemma of $A P$ VI 11, appears instead of the Satyros name

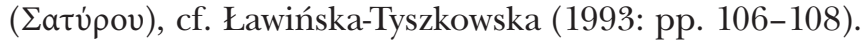

Also the content of the epigram seems to speak for the early Hellenistic origin of the epigram. The bizarre terms referring to the Damoetas' profession (e.g. тò $\pi \dot{\varepsilon} \tau \rho\rceil \varsigma$

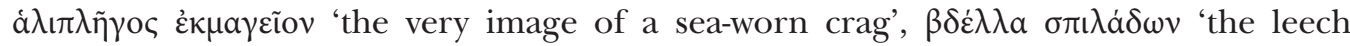
of the rocks') could have appeared in the erudite period of the Alexandrian era, when poetry was created by Phalaecus of Phocis, the poet from the fourth or third century BC. These unusual phrases could be derived from the tradition of the socalled "new dithyrambus", whose characteristic feature was the inclination to strange,

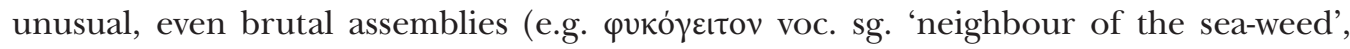
ó $\beta \cup \sigma \sigma o \mu \varepsilon \dot{\tau} \tau \eta \varsigma$ 'the fathomer of the deep' and so on). The poets of the "new dithyrambus" preferred a style full of complex periphrases, metonymies, giving new meanings

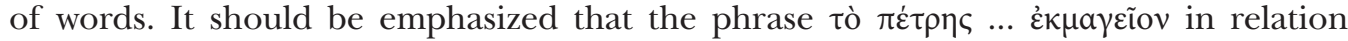
to man appears only in this epigram (Abramowiczówna 1960: p. 71). Also the poets in question used a very complex metric structure. Note that a free-form Phalaecian hendecasyllable appears in $A P$ VI 193 instead of the most popular metrical form in epigrams, which was the elegiac distich. The linguistic experiments of the dithyrambic poets, especially of Timotheus of Miletus (ca. 450 - ca. 360 BC), seem to be still 
present in the epigram AP VI 193. These observations point to Phalaecus of Phocis as the author of this votive dedication rather than to Statyllius Flaccus, a poet working during the era of Roman domination.

The third premise for Phalaecus' authorship is the metre used in AP VI 193, namely the so-called Phalaecian hendecasyllable (Lat. versus hendecasyllabus Phalaeceus). This metre was known and used already in the archaic period, but it received its name from the Alexandrian poet Phalaecus of Phocis (4th or 3rd c. BC) (Appel 1979: pp. 259-260; 2016: p. 15). This was probably called after him, because Phalaecus often had to use the metre in question and even in the general opinion he was regarded as its main propagator. In fact, he used various metrical forms, for as many as three of his epigrams went to the thirteenth book of the Palatine Anthology (AP XIII 5, 6 and 27), containing epigrams written in various meters. In one of them, Phalaecus of Phocis introduced the iambic trimeter ( $A P$ XIII 5), in the second he used the Phalaecian hendecasyllable ( $A P$ XIII 6), and in the third a fairly complex meter composed of dactylic epitrites (specifically the dactylic tetrameter with the ithyphallic) applied alternately with the hexameter and at the same time interlaced by iambic trimeters (AP XIII 27). Because the Phalaecian hendecasyllable (Lat. versus hendecasyllabus Phalaeceus), named after Phalaecus of Phocis, was used in the epigram $A P$ VI 193, so in the case of the alternative lemmas $\Phi$ aıkiov (?) ( $\left.\mathrm{P}^{1}\right)$ or $\Phi \lambda$ ákкov (scribe c), it is right to opt for the poet of Phocis as a more credible author of the epigram in question (Witczak 2005: pp. 130-136). This conclusion is all the more likely, as Statyllius Flaccus used only one meter in all epigrams firmly attributed to him (namely the elegiac distich).

\section{The authorship of AP VI 165}

The votive epigram $A P$ VI 165, written in the Ionic dialect, describes a woman called Euanthe, who dedicates her corybantic instruments to Dionysus Bacchus.

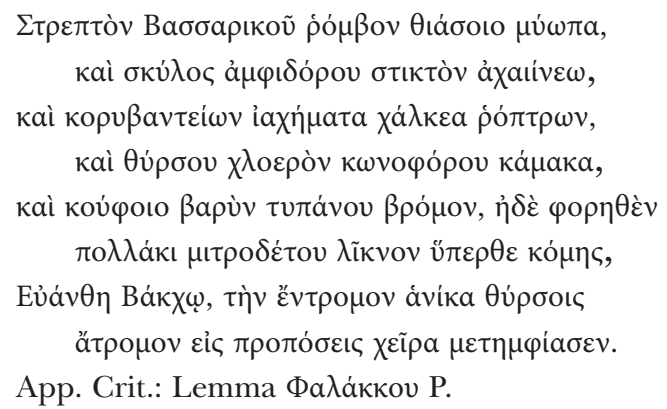

English translation: „Evanthe, when she transferred her hand from the unsteady service of the thyrsus to the steady service of the wine-cup, dedicated to Bacchus her whirling tambourine that stirs the rout of the Bacchants to fury, this dappled spoil of a flayed fawn, her clashing brass corybantic cymbals, her green thyrsus surmounted by a pine- 
cone, her light, but deeply-booming drum, and the winnowing-basket she often carried raised above her snooded hair”. Translated into English by Paton (1960a: p. 383).

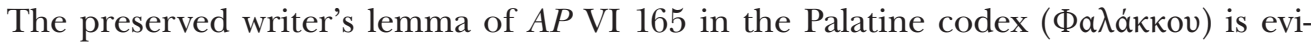
dently ambiguous: Two obvious possibilities should be taken into account: Фa入aíко

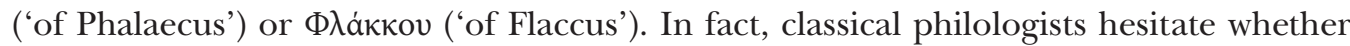
Phalaecus of Phocis or Statyllius Flaccus should be assumed as the author of AP VI 165.

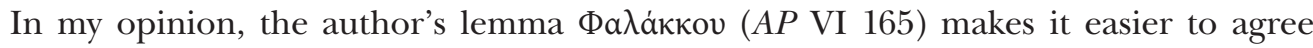

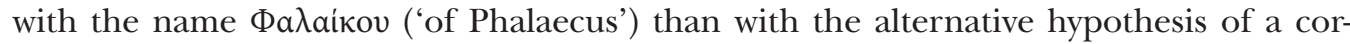

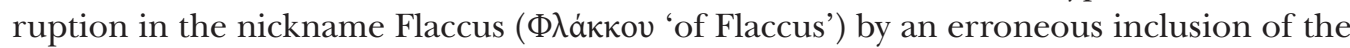
letter $\alpha$. The same statement is given by Stadtmueller (1894: p. 308), Waltz (1960: p. 91), Paton (1960a: p. 383) and Skiadas (1967-1968: pp. 74-76), who attribute the epigram in question to Phalaecus of Phocis. Also Page (1981: p. 47) observes that the epigram in question "is very different from anything else ascribed to Flaccus". He adds the following words: "The authorship of the epigram thus remains quite uncertain; perhaps there were two (or more) authors named 'Flaccus'" (Page 1981: 47). In this situation, it is desirable to include AP VI 165 to Phalaecus' literary output.

\section{Conclusions}

The analysis of three Greek epigrams included in the so-called Palatine Anthology (AP VI 165, VI 193, VII 650) makes plausible that:

(1) Statyllius Phlaccus cannot be treated as an author of these poetical masterpieces;

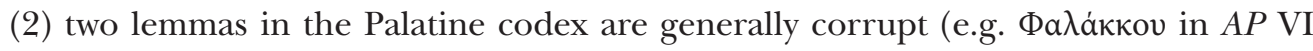

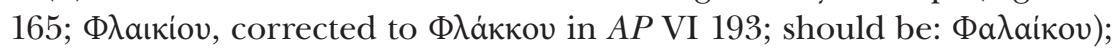

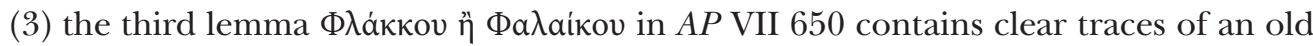
ambiguity (of ancient or mediaeval origin);

(4) the epigrams under discussion should be ascribed to Phalaecus of Phocis for lexical, metrical and formal reasons.

\section{Bibliography}

Abramowiczówna, Z. (Ed.). (1960). Stownik grecko-polski (Vol. II). Warszawa: Państwowe Wydawnictwo Naukowe.

Albiani, M. G. (2004). “Statilius Flaccus”. In H. Cancik, \& H. Schneider (Eds.), Brill's New Pauly: Encyclopaedia of the Ancient World (Vol. 5; col. 448). Leiden - Boston: Brill.

Albiani, M. G. (2007). "Phalaecus". In H. Cancik, \& H. Schneider (Eds.), Brill's New Pauly: Encyclopaedia of the Ancient World (Vol. 10; col. 906). Leiden - Boston: Brill.

Appel, W. (1979). Nieśmiertelność imienia, czyli rzecz o Falajkosie. Filomata, 325, 257-263.

Appel, W. (2017). Zagadka Syren. Filologa peregrynacje od antyku po wspótczesność. Toruń: Wydawnictwo Naukowe Uniwersytetu Mikołaja Kopernika. 
Davico Bonino, G. (Ed.). (2000). Antologia Palatina. Tutte le poesie d'amore (Traduzione di F. M. Pontani). Torino: Giulio Einaudi editore.

Ebener, D. (1981). Die griechische Anthologie, II: Buch VII-X. Berlin - Weimar: Aufbau-Verlag.

Gow, A. S. F., \& Page, D. L. (Eds.). (1965). Greek Anthology. Hellenistic Epigrams (Vol. II). Cambridge: Cambridge University Press.

Ławińska-Tyszkowska, J. (1993). Satyros epigramatyk. Classica Wratislaviensia, XVII (Acta Universitatis Wratislaviensis, 1523; pp. 101-109). Wrocław: Wydawnictwo Uniwersytetu Wrocławskiego.

Page, D. L. (Ed.). (1975). Epigrammata Graeca. Oxonii: E typographo Clarendoniano.

Page, D. L. (Ed.). (1981). Further Greek Epigrams. Epigrams before A.D. 50 from the Greek Anthology and other sources not included in 'Hellenistic Epigrams' or 'The Garland of Philip'. Cambridge: Cambridge University Press.

Paton, W. R. (1960a). The Greek Anthology (with an English Translation by W. R. Paton; Vol. I). London: William Heinemann Ltd. - Cambridge, Mass.: Harvard University Press.

Paton, W. R. (1960b). The Greek Anthology (with an English Translation by W. R. Paton; Vol. II). London: William Heinemann Ltd. - Cambridge, Mass.: Harvard University Press.

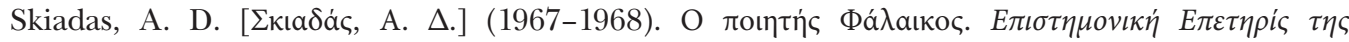

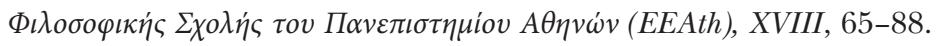

Stadtmueller, H. (1894). Anthologia Graeca epigrammatum Palatina cum Planudea (Vol. I). Lipsiae: B. G. Teubner.

Stadtmueller, H. (1899). Anthologia Graeca epigrammatum Palatina cum Planudea (Vol. II, Pars prior). Lipsiae: B. G. Teubner.

Tueller, M. A. (Ed.). (2014). The Greek Anthology. Books 1-5 (Transl. by W. R. Paton). Cambridge, Mass. - London: Harvard University Press.

Waltz, P. (Ed.). (1960). Anthologie grecque. Première partie: Anthologie Palatine. Tome III: livre VI. Paris: Société d'édition «Les Belles Lettres».

Waltz, P. (Ed.). (1960a). Anthologie grecque. Première partie: Anthologie Palatine. Tome V: livre VII, épigr. 364-748). Paris: Société d'édition «Les Belles Lettres».

Witczak, K. T. (2005). Falajkos czy (Statyllios) Flakkos? Głos w sprawie autorstwa epigramatu AP VI 193. In M. Wróbel (Ed.), Euterpe, Terpsichore, Erato. Liryka grecka i jej recepcja. Ksiegga pamiatkowa prof. Alicji Szastyńskiej-Siemion w siedemdziesiata rocznicę urodzin przez przyjaciót, kolegów, uczniów ofiarowana (Classica Wratislaviensia, XXVI; Acta Universitatis Wratislaviensis, 2715; pp. 130-136). Wrocław: Wydawnictwo Uniwersytetu Wrocławskiego.

Prof. dr. hab. Krzysztof Witczak / ktw@uni.lodz.pl

Department of Linguistics and Latin Studies

University of Łódź, Faculty of Philology

Pomorska 171/173, 90-236 Łódź, Poland 